\title{
Effect of Establishment Methods and Nutrient Management on Yield and Economics of Kharif Rice (Oryza sativa L.)
}

\author{
A. M. Yadav*, L. S. Chavan, A. R. Chavan and V. A. Rajemahadik \\ Department of Agronomy, College of Agriculture, Dr. Balasaheb Sawant Konkan Krishi \\ Vidyapeeth, Dapoli, Maharashtra, India \\ *Corresponding author
}

A B S T R A C T

\begin{tabular}{l} 
Ke y w or d s \\
$\begin{array}{l}\text { Rice, Methods, } \\
\text { Nutrient } \\
\text { management, Yield } \\
\text { and economics }\end{array}$ \\
\hline Article Info \\
\hline $\begin{array}{l}\text { Accepted: } \\
15 \text { November } 2019 \\
\text { Available Online: } \\
10 \text { December } 2019\end{array}$ \\
\hline
\end{tabular}

Field experiment was conducted at Agronomy Department Farm, College of Agriculture, Dapoli. Dist. Ratnagiri during Kharif seasons 2017 and 2018 to study the "Effect of establishment methods and nutrient management on yield and economics of Kharif rice (Oryza Sativa L.)". The field experiment was laid out in a strip plot design comprising of twelve treatment combinations replicated thrice. The horizontal strips comprised four rice establishment methods viz., sowing of dry seeds by drum seeder at onset of monsoon $\left(M_{1}\right)$, SRI (System of Rice Intensification) method $\left(M_{2}\right)$, Transplanting by hand operated transplanter $\left(\mathrm{M}_{3}\right)$ and Conventional transplanting $\left(\mathrm{M}_{4}\right)$. The vertical strips consisted three nutrient management treatments viz., $100 \%$ RDN through organics $\left(\mathrm{N}_{1}\right), 100 \%$ RDF through inorganics $\left(\mathrm{N}_{2}\right)$ and application of $50 \%$ RDN through organics $+50 \%$ RDF through inorganics $\left(\mathrm{N}_{3}\right)$. The highest grain and straw yield from Kharif rice were obtained when rice crop was established by conventional transplanting method with application of $100 \% \operatorname{RDF}\left(\mathrm{M}_{4} \mathrm{~N}_{2}\right)$ or transplanting by SRI method $\left(\mathrm{M}_{2} \mathrm{~N}_{2}\right)$ as compared to remaining treatment combinations during pooled analysis. The highest net returns and benefit cost ratio was observed in transplanting by hand operated transplanter and application of $100 \%$ RDF or INM during both years and pooled mean.

\section{Introduction}

Rice (Oryza sativa L.) is the most important staple food crop of the world and India, feeding more than half of the world's population every day. Rice provides 20 per cent of the world's dietary energy supply, while wheat supplies 19 per cent and maize 5 per cent (FAO, International year of rice,
2004). In Asia, it has a special significance, where about $90 \%$ of the rice is produced and consumed as a staple food. It is a predominant crop in lowland ecosystem. Globally it is cultivated in an area of 161.28 million hectares with an annual production of 715.75 million tonnes (Anonymous, 2016a) [1]. Among the various rice growing countries of the world, India has the largest area under rice 
and in case of production it stands next to China. In India, rice is the most important and extensively grown food grain crop, occupying an area of 44.11 million hectares with production of 105.48 million tonnes. However, productivity of India (2.39 tonnes $\left.\mathrm{ha}^{-1}\right)$ is lower than the world average yields ( 4.4 tonnes $\mathrm{ha}^{-1}$ ) and is much behind than the rice productivity of Egypt, Japan and China (Anonymous, 2016 b) [2]. Rice is also an important cereal food crop of Maharashtra State, which contributes 3.6 per cent of area and 2.8 per cent of production of rice at national level. Total area, production and productivity of rice were 14.71 lakh hectares, 25.17 lakh tonnes and 1.71 tonnes $\mathrm{ha}^{-1}$, respectively. Rice is the main food crop grown in Konkan region, which occupies an area of 3.79 lakh hectares with production 9.94 lakh tonnes and productivity of 2.61 tonnes $\mathrm{ha}^{-1}$ (Anonymous, 2016c) [3]. Rice is grown either by direct seeding or by transplanting. In Konkan, rice is mostly grown by transplanting method. Method of crop establishment influences the performance of rice through its effect on growth and development. Although, transplanting has been reported to be the best establishment method (Jana et al., 1981 and Singh et al., 1997) but due to high water and labour requirement, some alternatives like dry and wet direct seeding are being explored to ensure optimum yield at a lower cost. The results revealed that both transplanted and direct seeded method needed nearly equal investment on cultivation, but transplanted rice required more initial expenditure as compared to direct seeded rice. Weed infestation and weed competition are more in direct seeded rice as compared to transplanted rice, because the land is exposed till the initial seedling establishment in direct seeded rice.

Nutrient management provides an approach for feeding the plants with nutrients as and when required. Integrated use of organic manures and chemical fertilizers has advantages over use of only organic manures or chemical fertilizers (Kumar et al., 2009). Since sourcing of organic manure is difficult and the crop response to them during initial stages is not as spectacular, compared to the chemical fertilizers (Deka et al., 1996), an integrated approach of plant nutrition involving the judicious mix of organic, chemical and microbial sources could be helpful to sustain optimum yield and to restore the residual soil fertility. Keeping this in view, the present study was undertaken to investigate the effect of establishment methods and nutrient management on yield and economics of kharif rice.

\section{Materials and Methods}

The field experiment was conducted on plot Nos. 22 and 23 of 'B' block of Agronomy Department Farm, College of Agriculture, Dapoli. Dist. Ratnagiri during Kharif 2017 and 2018. The soil of the experimental plot was uniform, levelled and well drained. It was sandy clay loam in texture, low in available nitrogen $\left(214.42 \mathrm{~kg} \mathrm{ha}^{-1}\right)$, phosphorus $(9.62 \mathrm{~kg}$ $\left.\mathrm{ha}^{-1}\right)$ and medium in potassium (207.31 $\mathrm{kg} \mathrm{ha}^{-1}$ ), moderately high in organic carbon $(0.95 \%)$ and slightly acidic in reaction (5.86). The sowing of dry seeds by drum seeder was done at onset of monsoon as per the treatments. The nursery for conventional transplanting, transplanting by hand operated transplanter and SRI method was done on the same day of sowing of dry seeds by drum seeder. In $100 \%$ RDF and 50\% RDF dose of integration, $40 \% \mathrm{~N}$ and all $\mathrm{P}$ and $\mathrm{K}$ was applied as basal dose and remaining $60 \% \mathrm{~N}$ was applied in two splits i.e. $40 \%$ at maximum tillering and $20 \%$ at panicle initiation stages. In $100 \%$ RDN through organics and 50\% RDN of integration, full doses were applied as basal as per the treatments. The other usual common packages of practices were followed time to time and periodical growth observations were recorded at an interval of 
30 days. Crop was harvested at physiological maturity and data on yield attributes and yield were recorded.

\section{Results and Discussion}

Effect of establishment methods on yield and economics of

\section{Kharif rice}

The highest grain and straw yield were recorded when the rice established by conventional transplanting as compared to other establishment methods during individual years as well as in pooled data.

Among transplanting methods conventional transplanting remained at par with SRI and produced higher grain yield than rice planted by hand operated transplanter during individual years. Further, SRI method produced statistically identical grain yield to that of hand operated transplanter during both the years of study.

Submerged conditions in transplanted rice facilitate efficient weed management and balanced nutrition that might have encouraged higher growth, tillers and panicles production and contributing to higher dry matter production and grain yield. However, the net returns and $\mathrm{B}: \mathrm{C}$ ratio differed with the different crop establishment methods with transplating by hand operated transplanter recording the highest net returns and $\mathrm{B}: \mathrm{C}$ ratio followed by CT, SRI and DSR.

The economics clearly indicated that though the grain and straw yield of rice was significantly higher due to conventional transplanting and SRI, higher yields did not compensate the expenditure incurred for transplanting of seedlings in both the methods. These findings corroborate earlier reports by
Subbulaxmi et al., (2008) and Geethalaxmi et al., (2011).

\section{Effect of nutrient management on yield and economics of Kharif rice}

Data pertaining to the grain, straw yields ( $q$ $\left.\mathrm{ha}^{-1}\right)$, net returns and $\mathrm{B}: \mathrm{C}$ ratio as influenced by different treatments are presented in Table 1 and 2 indicated that, application of $100 \%$ RDF through inorganic $\left(\mathrm{N}_{2}\right)$ and Integrated nutrient management $\left(\mathrm{N}_{3}\right)$ recorded significantly higher grain and straw yield over organic treatment $\left(\mathrm{N}_{1}\right)$ during individual years as well as in pooled data.

However, application of $100 \%$ RDF recorded higher net returns and $\mathrm{B}: \mathrm{C}$ ratio. The increase in grain yield was might be due to application of mineral $\mathrm{N}, \mathrm{P}$ and $\mathrm{K}$ that significantly increased growth and yield attributes which in turn, increased the rice yield compared to added levels of $\mathrm{N}$ and other nutrients in organic form. The similar findings were also reported by Dash et al., (2011), Sujatha (2013), Meena et al.,(2014), Patel (2014), and Marskole (2017).

\section{Effect of establishment methods and nutrient management on yield of rice}

Among the interactions the highest grain and straw yield (46.46 and $65.26 \mathrm{q} \mathrm{ha}^{-1}$ ) were recorded with conventional transplanting method coupled with $100 \%$ RDF or INM and the lowest yield (35.21 and $51.40 \mathrm{q} \mathrm{ha}^{-1}$ ) in drum seeded rice with $100 \%$ RDN through organic $\left(\mathrm{N}_{1}\right)$, respectively (Table 3$)$. This can be ascribed to balanced nutrition of essential nutrients due to better physical, chemical and biological properties maintained under INM followed for transplanted rice. These findings corroborate the reports of Mohanty et al., (2014) and Moharana (2015) (Table 4). 
Table.1 Grain and straw yield ( $\mathrm{q} \mathrm{ha}^{-1}$ ) of rice as influenced by different treatments during Kharif 2017, 2018 and in pooled data

\begin{tabular}{|c|c|c|c|c|c|c|}
\hline \multirow[t]{2}{*}{ Treatments } & \multicolumn{3}{|c|}{ Grain yield $\left(q\right.$ ha $\left.^{-1}\right)$} & \multicolumn{3}{|c|}{ Straw yield $\left(q\right.$ ha $\left.^{-1}\right)$} \\
\hline & 2017 & 2018 & Pooled & 2017 & 2018 & Pooled \\
\hline \multicolumn{7}{|c|}{ Establishment methods } \\
\hline M1: Sowing of dry seeds by drum seeder & 35.82 & 34.93 & 35.37 & 53.35 & 50.59 & 51.97 \\
\hline M2: SRI method & 43.10 & 41.60 & 42.35 & 60.14 & 58.04 & 59.09 \\
\hline $\begin{array}{l}\text { M3: Transplanting by hand operated } \\
\text { transplanter }\end{array}$ & 42.30 & 40.07 & 41.18 & 56.34 & 53.03 & 54.68 \\
\hline M4: Conventional transplanting & 43.97 & 42.87 & 43.42 & 62.89 & 61.58 & 62.23 \\
\hline S.Em. \pm & 0.39 & 0.38 & 0.22 & 0.83 & 0.48 & 0.45 \\
\hline C.D. at 5\% & 1.35 & 1.32 & 0.75 & 2.86 & 1.65 & 1.55 \\
\hline \multicolumn{7}{|c|}{ Nutrient management treatments } \\
\hline N1: $100 \%$ RDN through organic & 38.63 & 37.93 & 38.28 & 55.51 & 52.63 & 54.07 \\
\hline N2: $100 \%$ RDF through inorganic & 43.15 & 41.32 & 42.20 & 59.71 & 57.93 & 58.82 \\
\hline N3: 50\% RDN through organic+50\% RDF & 42.11 & 40.36 & 41.23 & 59.32 & 56.87 & 58.09 \\
\hline S.Em. \pm & 0.30 & 0.41 & 0.34 & 0.81 & 0.28 & 0.43 \\
\hline C.D. at 5\% & 1.18 & 1.60 & 1.32 & 3.16 & 1.12 & 1.69 \\
\hline \multicolumn{7}{|c|}{ Interaction effect } \\
\hline S.Em. \pm & 1.27 & 0.98 & 1.09 & 1.90 & 1.75 & 1.60 \\
\hline C.D. at $\mathbf{5 \%}$ & 3.90 & NS & 3.36 & NS & NS & 4.93 \\
\hline General mean & 41.30 & 39.87 & 40.58 & 58.18 & 55.81 & 56.99 \\
\hline
\end{tabular}

Table.2 Net returns (Rs. ha ${ }^{-1}$ ) and benefit to cost ratio from rice as influenced by different treatments during Kharif 2017, 2018 and in pooled data

\begin{tabular}{|c|c|c|c|c|c|c|}
\hline \multirow[t]{2}{*}{ Treatments } & \multicolumn{3}{|c|}{ Net returns (Rs. ha-1) } & \multicolumn{3}{|c|}{ B: C ratio } \\
\hline & 2017 & 2018 & Pooled & 2017 & 2018 & Pooled \\
\hline \multicolumn{7}{|c|}{ Establishment methods } \\
\hline M1: Sowing of dry seeds by drum seeder & 16295 & 14434 & 15365 & 1.31 & 1.28 & 1.30 \\
\hline M2: SRI method & 17921 & 15309 & 16615 & 1.27 & 1.24 & 1.25 \\
\hline $\begin{array}{c}\text { M3: Transplanting by hand operated } \\
\text { transplanter }\end{array}$ & 22746 & 18601 & 20673 & 1.38 & 1.32 & 1.35 \\
\hline M4: Conventional transplanting & 19800 & 18001 & 18900 & 1.29 & 1.27 & 1.28 \\
\hline S.Em. \pm & 592 & 602 & 353 & 0.01 & 0.01 & 0.01 \\
\hline C.D. at $5 \%$ & 2049 & 2083 & 1220 & 0.03 & 0.03 & 0.02 \\
\hline \multicolumn{7}{|c|}{ Nutrient management treatments } \\
\hline N1: $100 \%$ RDN through organic & 9185 & 7299 & 8242 & 1.10 & 1.08 & 1.09 \\
\hline N2: $100 \%$ RDF through inorganic & 33680 & 30708 & 32194 & 1.63 & 1.58 & 1.61 \\
\hline N3: $50 \%$ RDN through organic $+50 \%$ RDF & 14705 & 11752 & 13229 & 1.21 & 1.17 & 1.19 \\
\hline S.Em. \pm & 269 & 456 & 285 & 0.01 & 0.01 & 0.01 \\
\hline C.D. at 5\% & 1055 & 1791 & 1119 & 0.03 & 0.04 & 0.03 \\
\hline \multicolumn{7}{|c|}{ Interaction effect } \\
\hline S.Em. \pm & 1529 & 1330 & 1311 & 0.03 & 0.03 & 0.03 \\
\hline C.D. at 5\% & NS & NS & NS & NS & NS & NS \\
\hline General mean & 19190 & 16586 & 17888 & 1.31 & 1.28 & 1.30 \\
\hline
\end{tabular}


Table.3 Interaction effects between of establishment methods and nutrient management on grain yield ( $\mathrm{q} \mathrm{ha}^{-1}$ ) of rice during Kharif 2017 and pooled mean

\begin{tabular}{|c|c|c|c|c|c|c|c|c|}
\hline & & & & \multicolumn{5}{|c|}{ Grain yield $\left(q\right.$ ha $\left.^{-1}\right)$} \\
\hline & \multicolumn{4}{|c|}{2017} & \multicolumn{4}{|c|}{ Pooled mean } \\
\hline & $\mathbf{M}_{1}$ & $\mathbf{M}_{2}$ & $\mathbf{M}_{3}$ & $\mathbf{M}_{4}$ & $\mathbf{M}_{1}$ & $\mathbf{M}_{2}$ & $\mathbf{M}_{3}$ & $\mathbf{M}_{4}$ \\
\hline $\mathbf{N}_{1}$ & 35.21 & 39.32 & 39.37 & 40.62 & 34.85 & 39.23 & 38.33 & 40.72 \\
\hline $\mathbf{N}_{2}$ & 36.79 & 45.50 & 43.86 & 46.46 & 36.24 & 44.28 & 42.73 & 45.69 \\
\hline $\mathbf{N}_{3}$ & 35.45 & 44.49 & 43.67 & 44.82 & 35.04 & 43.54 & 42.50 & 43.86 \\
\hline $\begin{array}{c}\text { S.Em. } \\
\pm .\end{array}$ & \multicolumn{4}{|c|}{1.27} & \multicolumn{4}{|c|}{1.09} \\
\hline $\begin{array}{r}\text { C.D. } \\
\text { at 5\% }\end{array}$ & \multicolumn{4}{|c|}{3.90} & \multicolumn{4}{|c|}{3.36} \\
\hline
\end{tabular}

Table.4 Interaction effect of establishment methods and nutrient management treatments on straw yield $\left(\mathrm{q} \mathrm{ha}^{-1}\right)$ of rice in pooled analysis

\begin{tabular}{|c|c|c|c|c|}
\hline & \multicolumn{4}{|c|}{ Straw yield $\left(q\right.$ ha $\left.^{-1}\right)$} \\
\hline & \multicolumn{4}{|c|}{ Pooled mean } \\
\hline & $\mathbf{M}_{1}$ & $\mathbf{M}_{2}$ & $\mathbf{M}_{3}$ & $\mathbf{M}_{4}$ \\
\hline $\mathbf{N}_{1}$ & 51.40 & 55.85 & 51.74 & 57.30 \\
\hline $\mathbf{N}_{2}$ & 53.03 & 60.69 & 56.30 & 65.26 \\
\hline $\mathbf{N}_{3}$ & 51.48 & 60.74 & 56.00 & 64.15 \\
\hline S.Em. \pm & \multicolumn{4}{|c|}{1.60} \\
\hline $\begin{array}{c}\text { C.D. at } \\
\mathbf{5 \%}\end{array}$ & \multicolumn{4}{|c|}{4.93} \\
\hline
\end{tabular}

From the results of the present investigation, it can be concluded that highest grain and straw yield from Kharif rice was obtained when rice crop was established by conventional transplanting method and highest net returns ad benefit to cost ratio was recorded under transplanting by hand operated transplanter with application of $100 \%$ RDF or INM.

\section{References}

Anonymous. Rice Statistics Online Query Facility. International Rice Research Institute, $2016^{\mathrm{a}}$.

Anonymous. Annual report 2016-2017, Department of Agriculture and Cooperation, Ministry of Agriculture, Government of India, 2016 ${ }^{\mathrm{b}}$.
Anonymous. Final estimates of area, production and productivity of principal crops during 2015-16 in M.S., Department of Agriculture, Government of Maharashtra, 2016 $\mathrm{c}$.

Dash, A. C., Saren, B. K and Roul, P.K (2017). Residual effect of nutrient management practices in hybrid rice under SRI on growth and yield of greengram (Vigna radiata) in ricegreengram cropping system, International Journal of Bioresource and stress management 8 (6):749-752.

Deka M.B, Barthakur H.P and Barthakur S.N (1996). Effect of organic and inorganic source of nitrogen on the nutrients in soil and soil solution and growth of 
rice. Journal of the Indian Society of Soil Science 44: 263-266.

Geethalakshmi V, Ramesh T, Palamuthirsolai A and Lakshmanan 2011. Agronomic evaluation of rice cultivation systems for water and grain productivity. Archives of Agronomy and Soil Science 57 (2): 159-166

Jana, P.K., Haldar, S.K., Mandal, B.B., (1981). Performance of rice varieties to levels of nitrogen and method of planting. Food Farming and Agriculture. 13(11/12), 194-197.

Kumar R.M, Surekha K, Padmavathi C, Subbarao L.V, Latha P.C, Prasad M.S, Ravindrababu V, Ramprasad A.S, Rupela O.P, Goud V, Muthuraman P, Somashekhar N, Ravichandran S.M, Singh S.P and Viraktamath B.C 2009. Research experiences on system of rice intensification and future directions. Journal of Rice Research 2(2): 61-71.

Marskole, V. (2017). Effect of nutrient management on productivity and economics of rice. Unpublished thesis submitted to Jawaharlal Nehru Krishi Vishwa Vidyalaya, Jabalpur, M.P.

Meena, M., Patel, M, V., Das, T and Verma, H, P (2014). Effect of organic sources and nitrogen levels on growth and yield of kharif rice (oryza sativa 1.) under SRI technique. Agriculture for Sustainable Development 2(1):39-42.

Mohanty, T. R., Maity, S. K., Roul, P. K. and Sahoo, K. C. (2014). Studies on yield, economics and energetics of rice
(Oryza sativa L.) in relation to crop establishment methods and nutrient management practices. Intern. J. Bioresource and Stress Manag., 5 (4): 495-501.

Moharana, A. (2015). Effect of plant establishment method and organic source of nutrient on rice. M.sc (Agri), unpublished thesis submitted to Orissa University of Agriculture and Technology, Bhubaneswar.

Patel, A.(2014). Effect of integrated nutrient management on growth and yield of wetland rice (Oryza sativa L.). M.Sc (Agri) Unpublished thesis submitted to Institute of Agricultural Sciences Banaras Hindu University Varanasi221005.

Singh, K.M., Pal, S.K., Verma, U.N., Thakur, R., Singh, M.K., 1997. Effect of time and methods of planting on performance of rice cultivars under medium land of Bihar plateau. Indian Journal of Agronomy 42(3), 443-445.

Subhalakshmi, C. and Reddy, A.K. (2014). Spikelet sterility in hybrid rice (Oryza sativa $\mathrm{L}$.) as influenced by sources and levels of nutrients. Curr. Adv. Agric. Sci., 6 (1):49-51.

Sujatha (2013). Yield, quality and nutrient uptake of rice as affected by time and application of organic sources of nitrogen. M.Sc (Agri) unpublished thesis submitted to Agricultural college, bapatla - 522101 Acharya N. G. Ranga Agricultural University.

\section{How to cite this article:}

Yadav, A. M., L. S. Chavan, A. R. Chavan and Rajemahadik, V. A. 2019. Effect of Establishment Methods and Nutrient Management on Yield and Economics of Kharif Rice (Oryza sativa L.). Int.J.Curr.Microbiol.App.Sci. 8(12): 2040-2045. doi: https://doi.org/10.20546/ijcmas.2019.812.241 